\begin{tabular}{|lr|}
\hline $\begin{array}{l}\text { Social Work/Maatskaplike Werk Vol } 56 \text { No 3; Issue } 1 \\
\text { http://socialwork.journals.ac.za/pub }\end{array}$ & doi:http://dx.doi.org/10.15270/56-3-854 \\
\hline
\end{tabular}

THE FOURFOLD NEOLIBERAL IMPACT ON SOCIAL WORK AND WHY THIS MATTERS IN TIMES OF THE COVID-19 PANDEMIC AND BEYOND

A Ornellas, L Engelbrecht, E Atamtürk

While social welfare policy forms a cornerstone of the social work profession, economic policy and its interactions often remain distant and of academic interest only. In this paper the authors argue that understanding how economic policy is impacting upon the profession is important for its day-to-day practice. This has become ever more apparent in the wake of the Covid-19 pandemic, which has affirmed social work as an essential service. In particular, the authors argue that the global impact of neoliberal economics on the day-to-day practices of social workers is fourfold in terms of the marketisation, consumerisation, managerialisation and deprofessionalisation of social work.

Dr Abigail Ornellas, Postdoctoral Research Fellow, Department of Social Work, Stellenbosch University, South Africa. Prof Lambert Engelbrecht, Professor and Departmental Chair, Department of Social Work, Stellenbosch University, South Africa.

Mr Elvan Atamtürk, Lecturer, Department of Social Work, Kocaeli University, Turkey.

Abigail Ornellas, Orcid:0000-0003-0751-4752

Lambert K. Engelbrecht, Orcid: 0000-0001-6549-7183

Elvan Atamtürk, Orcid: 0000-0002-6538-4792

abiornellas@gmail.com

$\underline{\text { lke@sun.ac.za }}$

elvan.atamturk@kocaeli.edu.tr

Keywords: Covid-19, deprofessionalisation, neoliberalism, managerialism, social work practice, social work management 


\title{
THE FOURFOLD NEOLIBERAL IMPACT ON SOCIAL WORK AND WHY THIS MATTERS IN TIMES OF THE COVID-19 PANDEMIC AND BEYOND
}

\author{
A Ornellas, L Engelbrecht, E Atamtürk
}

\section{INTRODUCTION}

Social workers are having to function in an increasingly challenging world. At the heart of this challenge is a global neoliberal reform, which has become the dominant international framework for globalisation and economic development (Harvey, 2014; Ornellas, Spolander, Engelbrecht, Sicora, Pervova, Martínez-Román, Law, Shajahan, Das Dores Guerreiro, Casanova, Garcia, Acar, Martin \& Strydom, 2019). The adverse implications of neoliberalism have been widely recognised in academic literature in different spheres of the world (see, for example, Harvey, 2005, 2007; Hay, 2002; Ife, 2000; Midgley, 1997; Ornellas \& Engelbrecht, 2020; Spolander, Engelbrecht \& Pullen-Sansfaçon, 2016). The key conclusions of these studies are that neoliberal policies have been linked to growing inequality, and that the consolidation of wealth and power is in the hands of an elite few. A neoliberal discourse has a growing emphasis on the prioritisation of economics and financial gain over matters of social justice, and the prioritisation of the individual over the collective. Neoliberalism has also been linked to increasing environmental degradation and community displacement, the commodification of care, and the privatisation of social welfare. All of the above have become glaringly apparent in the global economic impact of the Covid-19 pandemic.

For many social workers the arena of economics and economic policy is, however, of less concern: social workers are overwhelmed by the daily challenges of their practice and while social policy and legislation form a cornerstone of the profession, economic argument and theory remain academic and distant concerns (Ornellas \& Engelbrecht, 2020). However, as has now become evident through the Covid-19 pandemic, economic policy directly affects social work practices. With the profession deemed an essential service in the fight against the pandemic on global and local levels, the day-to-day tasks of social workers in the midst of the devastation of the pandemic are centred on people's survival; this depends alia on inter the economic policies governing bodies implement, which impact on the communities, families and individuals served by social workers. The discourse driving a country's economic decision-making is now, more than ever, cutting to the very core of the social work profession.

Against this backdrop, the authors argue that an understanding of the broader national and international economic policies and the way that they are impacting upon the profession is of paramount importance for social workers' day-to-day practices. Four categories of neoliberal tenets are identified that may impact on the day-to-day practices of social workers: (i) marketisation; (ii) consumerisation; (iii) managerialisation; and (iv) deprofessionalisation. The notions of key authors such as Howe (1996), Jones (2001), Harris $(2003$; 2014) and Harvey (2014) will be used to describe the relationship between neoliberalism and social work, and this will be complemented with the few relevant contemporary social work studies on the topic. Although South African case studies, such as those by Engelbrecht (2015) and Ornellas and Engelbrecht (2020), are referenced to substantiate some of the arguments in this article, broader comparative international studies such as those by Ornellas, Engelbrecht, MartínezRomán, Tortosa-Martínez, Casanova and Das Dores Guerreiro, (2017), Ornellas et al. (2019) and Spolander et al. (2014)will also be used to highlight the fact that the impact of neoliberalism on social work is a universal phenomenon.

The thrust of the argument in this article is that the social work profession needs to accurately position itself within socioeconomic shifts to be able to identify and tackle the underlying macro and structural causes of many of the social challenges facing families and communities, specifically since the start of the millennium (compare Harris, 2003; Howe, 1996; Jones, 2001). Furthermore, the social work profession needs to understand current and future challenges, not only for civil wellbeing in general, but for social service delivery in particular (compare Ornellas \& Engelbrecht, 2020; Spolander, 2019), 
which stems from the ruling economic theory of our time. The conclusion in this article points to the fact that the social work profession has been, and continues to be, impacted upon by a neoliberal discourse on the level of its daily practices. However, it is only through critical consciousness of this impact that social workers can respond appropriately and, where necessary, resist, even during the crisis times of the Covid-19 pandemic, when social work may be focused chiefly on immediate crisis interventions.

\section{THE FOUNDATION OF SOCIAL WORK: DO CAPITALIST BEGINNINGS MAKE FOR NEOLIBERAL CONCERNS?}

The International Federation of Social Workers (IFSW), 2014 and the International Association of Schools of Social Work (IASSW) are governed by internationally agreed upon values and principles outlined in a globally accepted, and regularly revised, definition. The profession's most recent definition, as asserted by the IFSW and IASSW in 2014, reads as follows:

Social work is a practice-based profession and an academic discipline that promotes social change and development, social cohesion, and the empowerment and liberation of people. Principles of social justice, human rights, collective responsibility and respect for diversities are central to social work. Underpinned by theories of social work, social sciences, humanities and indigenous knowledge, social work engages people and structures to address life challenges and enhance wellbeing. The above definition may be amplified at national and/or regional levels (IFSW, 2014).

This definition was agreed upon through numerous in-depth consultations with representatives from over 110 countries. In examining this definition, Ornellas, Spolander and Engelbrecht (2018) identified three critical shifts from the previous definition along with its broader commentary and analysis, which had been standing since 2012. These shifts included:

- The strengthening of theory and knowledge: This definition reiterated the broad scientific knowledge base of the profession and highlighted the significance of indigenous theory (in critique of the previous dominance of a Western bias);

- A shift from individualism to collectivism: The previous definition (2012) had been heavily criticised for its reliance on individualism and its advocation for service delivery that worked from the inside outward. The new definition (2014) calls for a commitment to collectivism, in line with its promotion of social and economic justice;

- A shift from micro-heavy to increased macro understandings of inequality and social problems: While moving away from an individual-centric position, the revised social definition recognises the underlying structural causes of challenges facing communities and emphasises a collective macro approach that works from the outside inward to dismantle the structural roots of social problems.

Principles such as collectivism, addressing the structural causes of social problems, and reinvigorating the scientific and academic strengths of the profession, come into direct conflict with many marketcentric ideals the find expression in today's socioeconomic discourse, including individualism, marketisation, individual responsibility, welfare cutbacks and a perpetuation of inequality. Hence, social work as a profession seems to be in conflict with the global neoliberal agenda. Therefore, it is imperative that social work practitioners understand how the neoliberal model is impacting on the profession's functioning, interventions and development, as well as on the communities it serves, so that it may respond appropriately. As highlighted by Ornellas et al. (2018: 235), core concepts such as social capital and social justice may be linked to, or co-opted by, the neoliberal concepts of self-help and a lack of consideration for the underlying structural influences and restraints on personal and social development; this implies that "unless social work is able to correctly identify the nature and causes of social distress, it will be unable to recommend and support appropriate interventions." 
The global social work definition should convince the profession that it is in fact not regulated by neoliberalism, but rather stands in contradiction to it. However, although this may be reflected as such on paper, it is not necessarily true of the profession's day-to-day practice (Ornellas \& Engelbrecht, 2020). It is important to note that social work is a contextual profession and demonstrates a history of being influenced by broader socioeconomic movements. Smith (2014), in her extensive review of social work development in South Africa and its links to capitalist drivers, for example, asserts that developments within the social work profession are not merely formed through a natural progression of theories and practices, but are in fact deeply contextual and shaped by broader conflicts and forces. The foundation for a critical consciousness as proposed in the global definition presented above requires reflection on not only the global value system of the profession, but the potential influence of underlying commitments and motivations that have formed part of the history of the profession, and how this can contribute to the profession's vulnerability to (and often unconscious compliance with) state-based economic policy agendas today.

Sewpaul and Hölscher (2004), for example, argue that the beginnings of Western social work in the $18^{\text {th }}$ and $19^{\text {th }}$ centuries were rooted in the dual processes of industrialisation and urbanisation. These two intertwined phenomena disrupted traditional lifestyles, including early familial forms of support and resulted in the rise of social problems within community groups at large, particularly at that time in urban slums, where wages were low and living conditions were poor. Sewpaul and Hölscher (2004: 19) also contend that during this period $\left(18^{\text {th }}\right.$ and $19^{\text {th }}$ century), the provision of public welfare was initially motivated by the interests of the upper classes, who "had the power to define social problems" and "determine which solutions were adequate or inadequate". Within this context, Pierson (1991: 22) observed that social work was seen as both "a response to working-class political pressure", as well as "a means of defusing the demand for further class-based and/or more revolutionary political action".

In the West, therefore, the profession arose partly from the state's desire to control urban poverty, illness and discontent which jeopardised capital interests (Clarke, 2004; Smith, 2014; Spolander, 2016). Similar arguments have been made for many developing countries (see, for example, Spolander, Engelbrecht, Martin, Strydom, Pervova, Marjanen, Tani, Sicora \& Adaikalam, 2014). As the profession has evolved throughout its history, it has continued to be subject to political influences and economic explanations of poverty and illness that have also been largely political in nature. Over time, however, with the rise of socialist democratic ideals of equity and fairness, the profession has evolved into a human-centred and protection- and rights-orientated caring science (Spolander et al., 2016) However, it is evident that social work's early commitments to social control, maintenance of the status quo, and protection of the elite continue to underlie some of its traditional motivations and practices. This has left social work as a profession vulnerable to political agendas and to practitioners who are often in a state of identity confusion.

It is within and through this contextual understanding that the profession's vulnerability to the impact of neoliberalism becomes significant in times of a global economic meltdown, such as during the Covid-19 pandemic. According to commentators such as Lymbery (2001), the contribution of social work to society has always been contested and, more recently, scholars such as Spolander (2019) have averred that putting economic policy into practice is resulting in social work professionals being susceptible to public devaluing of the services they provide, whether participatory or not, consciously or not.

\section{THE IMPACT OF THE COVID-19 PANDEMIC ON ECONOMIC AND SOCIAL WELLBEING}

In order to contextualise the argument that follows, in terms of the fourfold neoliberal impact on social work, it is necessary to offer a brief overview of the Covid-19 pandemic and its implications for global economic and social wellbeing. Since the novel coronavirus (2019-nCoV) was first recorded in China in late 2019, and subsequently officially declared as the Covid-19 pandemic by the World Health Organization (WHO), it has spread to more than 210 countries and territories around the world. 
Confirmed coronavirus cases increased tenfold in less than a month throughout the world, for example, from 100,000 in the first week of March 2020 to more than one million on 2 April 2020 (World Health Organization (WHO), 2020).

Beyond the devastating health implications of the virus, there have been the economic repercussions. In their attempts to contain the spread of the virus, countries have had to implement extreme measures, including nationwide limitations of movement and social distancing. The spread of the virus around the planet sent billions of people into lockdown as health services struggled to cope. These lockdowns are viewed by the International Monetary Fund as the worst economic downturn since the Great Depression (International Monetary Fund (IMF), 2020). Millions of people have lost their means of earning an income, aggravating existing inequalities (International Labour Organization (ILO), 2020). In the wake of this pandemic in countries such as South Africa, social work has been declared an essential service and has been one of the professions on the frontline of mitigating the socioeconomic and psychosocial impact of the disease (News 24, 2020).

\section{NEOLIBERALISM'S FOURFOLD IMPACT ON SOCIAL WORK PRACTICE}

The impact of neoliberalism, as briefly outlined earlier in the text, is varied and extensive. However, several tenets, can be identified as being at work particularly within the social work environment. Harris (2014), in his analysis of the neoliberal impact on the profession, identifies three propositions that are increasingly played out in social work day-to-day practice around the world as a result of the impact of neoliberal policies. He clusters these tenets in three categories:

- Marketisation (markets are efficient and effective and should be introduced in as many and as wide a range of contexts as possible);

- Consumerisation (individuals should be responsible for themselves and run their own lives);

- Managerialisation (services in the public or voluntary sectors should be modelled on management knowledge).

According to Harris (2014), these three categories represent a direction of influence on social work practices in many countries, and this has been confirmed by international research on six countries in Spolander et al. (2014) and on ten countries in Ornellas et al. (2019). However, an additional category may be added, which serves as an umbrella term for several neoliberal tenets impacting on social work, and which were specifically observed by Ornellas and Engelbrecht (2020). The fourth category that has been identified is:

- Deprofessionalisation (reducing professional discretion, deskilling social work and diminishing professional autonomy and identity).

Each of these categories contains a number of specific neoliberal tenets as assumptions, which can be explicitly identified in social work training, practice, management and professionalisation. The impact of these four neoliberal categories on social work practice is outlined in Figure 1 below.

From the exposition below, based on the illustration in Figure 1, it is evident that the social work profession may potentially be influenced by the prevailing economic and political forces, which inform social workers' decision-making, intervention choices, policies and practices. Ultimately, these categories of neoliberal tenets may be negatively affecting the profession and communities it serves. An analysis of each category is presented next in the light of its definition, followed by an explanation of how this particular category is at play in social work practice, contextualised within the Covid-19 pandemic. 
FIGURE 1

CATEGORIES OF NEOLIBERAL TENETS IMPACTING ON SOCIAL WORK (ADAPTED FROM HARRIS, 2014)
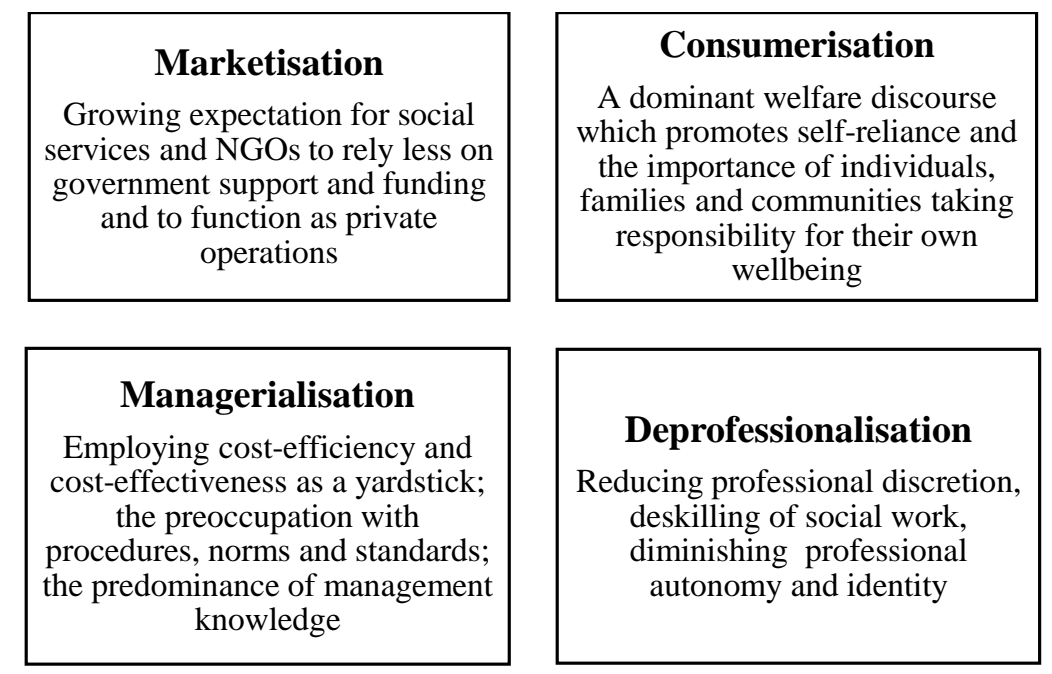

\section{Marketisation}

Neoliberal theory supports the assumption that markets are efficient and should be introduced in as many and as wide a range of contexts as possible (Harris, 2014; Ornellas, Engelbrecht \& Strydom, 2020). As described by Harvey (2007: 3), "Neo-liberalism holds that the social good will be maximised by maximising the reach of market transactions and it seeks to bring all human action into the domain of the market." Social welfare and consequently social work are thus often seen as representing the state's excessive spending, and neoliberalism advocates that such spending be shifted to the market, where it is believed that service delivery will be more efficient.

The adoption of such a principle within many country contexts has not always necessarily been demonstrated by an outright relieving of the state of its responsibilities. Instead, marketisation is often introduced under the guise of concepts such as development, community participation, grassroots interventions and the prioritisation of human rights (Spolander, 2019). Hence, the marketisation of welfare has several implications for social services and social work, which will be discussed next.

\section{Outsourcing of services}

A primary impact of neoliberal marketisation is the outsourcing of social services to private and NGO bodies, with the state distancing itself further from such responsibility. As outlined by Gray (1998: 25) over two decades ago, even though the emphasis is on "development ... civil society [has] to carry the greater load of human need ... camouflaging an abdication of the state's responsibility for welfare". The result is that in the current harsh economic times worldwide owing to the Covid-19 pandemic, social services and service providers such as NGOs (a primary employer of social workers in many countries) are expected to rely less on state resources, governance and provision, and instead are encouraged to operate as private entities based upon private sector principles and expectations. The effects of this are seen in the response to the Covid-19 pandemic, whereby NGOs were gravely affected by the economic downturn and the consequences of the vacuum that was created when their service delivery was removed became glaringly apparent.

The effect of marketisation is often demonstrated when previously state-provided services are increasingly shifted to the private sector, NGOs or communities. As outlined by Spolander et al. (2016), it is not necessarily a matter of reflecting on the nature of the work being undertaken by NGOs and private entities in the realm of social welfare, but rather an awareness of whether the state is increasingly taking responsibility for these services and offering structural support and investment. The impact this marketisation can have on social work is that in monopolistic conditions, marketisation, 
profit and competition can often become key drivers rather than the needs of the community. In such an environment the private sector can produce inefficient and expensive services in order to generate maximum profit (Flynn, 2007; Ornellas et al., 2020). Harris (2014) refers to this tendency as a race to the bottom on price alone.

Another impact of neoliberal marketisation on social work is the generating of private and expensive welfare services which become accessible only to the wealthy, leaving poorly resourced and undercapacitated NGO services to deal with vulnerable groups (Spolander, 2019), as is evident in the current Covid-19 crisis. It thus appears that where previously state expenditure financed public systems of provision in a manner that was independently and equally applied and monitored, neoliberalism has transformed such services, to which access if (or should be) every citizen's right, to a private market of competition and consumerism. The public provision of social welfare and social work is regarded as an alternative to, and in competition with, private provision, rather than a citizenship right. Public services are turned into commodities to be chosen by consumers; the choice between public and private thus becomes one of cost-effectiveness (Fine \& Leopold, 1993; Spolander, 2019). This can serve to maintain an existing status quo of inequality and perpetuate the concept of welfare for the poor as a burden on the state, especially in these times of the Covid-19 pandemic when governments want to kick-start their economies again.

\section{Dominance of contractual relationships}

A second consequence of marketisation for social work is a shift from rights-based services to services based on contractual relationships. Harris (2014) views this as being evident in social work discourse with the terminology shift from 'clients' to 'service users', who are then defined as consumers purchasing or contracting a service much like one would within a business environment. Neoliberal marketisation promotes this as a liberalisation of service users from their alleged roles as passive recipients of social work services, and instead empowers them as active, rational, self-interested, choice-making customers (Harris, 2014). However, the Covid-19 pandemic is teaching the world that most social work service users in the world do not have any choices at all as the coping with the pandemic is purely a matter of basic survival.

Ornellas et al. (2018) indicate that such an approach in social work can create an "us and them" narrative; Harris (2014) refers to this as an input-output social worker service-user relationship. Froggett (2002) expresses concerns, echoed by Spolander (2019), that such a shift in the working relationship between the social worker and the service user can create an expectation that service users can exercise rational discretion on their own behalf when engaging with social welfare services. This assumes that service users' needs are transparent, require no interpretation and are simply commodities to be purchased. The social worker-service user relationship thus becomes one where value-for-money is a primary consideration, which can undermine the social workers' interventions. The fact is, however, that value-for-money as a primary consideration for social work service users in times of the Covid-19 pandemic is in most cases not an option, as any assistance may make a difference, quite literally, between life and death.

\section{Markets enable governments to hold the consequences of their policies and funding levels at arm's length}

One of the characteristics of marketisation of social work services is that market outcomes can be presented as the result of impersonal forces that are defined as neither fair nor unfair (Harris, 2003). The impact of this for social work is that governments, while increasingly abdicating their responsibility for social welfare, can additionally deflect responsibility for the social justice consequences of policy changes and cuts, and instead appropriate markets to perform a powerful political legitimation function (Harris, 2014). Historically, social welfare held some form of autonomy and discretion in the socio-political play of society. Social work, although a profession deeply embedded in political values, was always able to maintain some distance from the conditions and 
dynamics of the capitalist market. However, marketisation is eroding this relative autonomy (Ferguson, Lavalette \& Whitmore, 2005; Ornellas \& Engelbrecht, 2020), and as a result, the antipathy of neoliberalism toward welfare finds expression in permeating social work with market-oriented relations and principles.

To be more specific: when a global crisis such as Covid-19 shakes the very core of a society, the urgent necessity for social work becomes apparent against the backdrop of private sector failure to meet citizens' needs. Many countries that have been pro-market (neoliberal) have had to, in the midst of the repercussions of the pandemic, implement nation-wide social protection schemes to mitigate the rising levels of poverty, not to mention deliver bailouts to businesses in order for them to stay afloat. This raises the question: why are governments only now responding with tangible measures to address social devastation (caused by a biological pandemic) and not in the past decades when levels of poverty and inequality were also conspicuously evident? The glaring levels of inequality that the marketisation of services perpetuates have been made ever more apparent in the current pandemic and communities are looking to government, not to business, to meet their socioeconomic and psychosocial needs.

\section{Consumerisation}

The second neoliberal category impacting upon social work is that of consumerisation. The primary influence of this set of neoliberal principles relates to the development of a dominant welfare discourse which promotes self-reliance and emphasises the importance of individuals, families and communities taking responsibility for their own wellbeing. Initially, such a discourse could be understood as empowering. However, when looked at more closely, and in combination with other neoliberal values and policies, the discourse of self-reliance is conjoined with state abdication of responsibility for citizens' basic rights and wellbeing. Instead, blame is directed at the individual for any social problems that may be experienced, regardless of whether these problems resulted from structural and policybased failures. Individuals are therefore held responsible for the challenges they face as a consequence of a state's shortcomings (Ornellas \& Engelbrecht, 2020). Shifting this level of responsibility onto the individual under the guise of empowerment perpetuates stigma and reinforces blame, and is used to accuse welfare systems of creating dependency. This approach in social work can often be detrimental to the service user and may be aptly summed up by the remark by Martin Luther King Jr.: "It's alright to tell a man to lift himself by his own bootstraps, but it is a cruel jest to say to a bootless man that he ought to lift himself by his own bootstraps" (1963). In similar vein, Harris (2014) argues that the impact of consumerisation and self-responsibility as discussed above serves to further encourage the shift role descriptions from service user, client and citizen to that of consumer. This category has three primary consequences for social work, which will be discussed next.

\section{The individualism vs. collectivism debate}

The concept of self-reliance as outlined above, can be linked strongly to an individual-collective debate. The neoliberal concept of individualism defines individuals as free, autonomous agents responsible for their own wellbeing. This individualistic prioritisation is clearly demonstrated by the current trend of both the marketisation and consumerisation of social work services (Ornellas \& Engelbrecht, 2020). Consumerism implies choice and autonomy, which equals freedom, and which generates further consumerism (Harris, 2014). As McDonald (2006: 127) puts it, in a neoliberal world "[t]he good citizen is one who wholeheartedly engages in an ongoing project of the personality defined by continuous consumption ... 'Freedom' is freedom to create personality and identity through the act of consumption." For instance, in social work practice, individualism and self-reliance (Sewpaul, 2013), as means of empowerment, have taken precedence over and above the development of a collective, caring and enabling socioeconomic environment. Thus, through neoliberal consumerisation, collective wellbeing of communities is proposed as being achieved through individual competition, success and responsibility. Accordingly, inequality is seen as a consequence of individual failure rather than of multiple and unseen macro and structural causes. 
Nevertheless, the individual versus the collective debate is not a new one in social work. The profession has long been conflicted in addressing these two opposing discourses, with community work and social change on the one end, and therapeutic individual and family-based intervention on the other (Staniforth, Fouché \& O'Brien, 2011). The profession's overemphasis on individualism and selfreliance was in fact offered as one of the critiques of the previous 2012 international definition of the profession, while the reviewed 2014 global definition placed more emphasis on collective and structural-orientated approaches (Ornellas et al., 2018). However, in practice, there is evidence that the concept of individualism remains deeply ingrained in social work intervention activities and approaches. For example, while some academics and practitioners suggest that social workers who practise counselling or therapeutic methods as their core functions have "sold out" (Staniforth et al., 2011: 193) and are not rooted in the concept of social justice, others would argue that individual change and the therapeutic role of the social worker remain a core intervention approach (Buchbinder, Eisikovits \& Karnieli-Miller, 2004). However, some arguments around this individualistic focus stem from capitalist roots (Sewpaul \& Hölscher, 2004) and such an individualistic emphasis in a neoliberal environment is more about survival of the fittest than it is a helping or empowering approach.

Therefore, it can be argued that the social work response to the Covid-19 pandemic, at the macro and policy level, and the services made available through public sector systems have embraced elements of universality, collectivism and equality, where social and political objectives, as collective concerns, take precedence over economic concerns. People can no longer be blamed for the circumstances in which they find themselves - the wage and contract worker, the uninsured, the unemployed - who are suffering greatly in this pandemic. Thus, the social worker may begin to recognise, now more than ever, that to empower the individual, requires certain collective conditions and actions.

\section{Neoliberal consumerism is derived from the private sector marketplace, where the goal is to encourage as much demand and consumption (and profit generation) as possible}

The second area of impact that emerges from the consumerisation of social work, through the promotion of the individual as a self-reliant and responsible consumer, is that there is a faulty assumption of a surplus of services and capacity that accompanies the notion of freedom of choice (Needham, 2006). The reality in social work, however, is that often the relationship between demand and resources does not always allow service users such abundant choice; the Covid-19 pandemic has confirmed this. Instead, through both the marketisation and consumerisation of social welfare, social workers are becoming increasingly overburdened with the management of scarce resources and capacity in the face of excessive demand (Harris, 2014). Vulnerable and impoverished communities are often not afforded the opportunity or economic ability to actively involve themselves in a competitive market that encourages consumer choice. As Butcher (1995: 161) contends, individuals (and thus also social work service users) may not always be in the position "where they can shop around and take their 'custom' elsewhere". This sentiment has been echoed by frontline social workers in recent research by Ornellas and Engelbrecht (2020) and is specifically evident in the current pandemic, as there may even be no alternative resource or service available to "take your custom to". Specialised NGOs, catering for abused women and children owing to family violence, who have to compete with their business proposals and plans for government funding and assistance, for example, may now find it more than ever extremely difficult to reach service users in times of lockdown (leading to potential family violence) during the Covid-19 pandemic, as they may have been under severe financial stress already, even before the outbreak of the pandemic.

An additional concerning impact of consumerisation as highlighted by Needham (2006) is that as a result of increased consumer demand and competition, with limited resources and service availability, individuals can often be turned away from services they require unless they are in a critical condition. As Needham (2006: 856) observed, service users are "being told that they will not receive a service until they get worse". In addition, in South Africa basic social protection and developmental services, for example, are primarily focused on the "poorest citizens" (Department of Social Development 
(DSD), 2016: 5). Thus, the devastating triage actions, which many hospitals were forced to undertake when admitting and treating Covid-19 patients, based on the severity of their illness and likelihood of survival in the wake of limited healthcare, and citizens who have to prove that they are the poorest of the poor, is facing the absolutely worst-case scenario. This does not encourage empowerment or the generation of wellbeing, nor does it allow for the appropriate (and necessary) implementation of preventative services that are often far more financially and socially effective. Therefore, the contradiction is that rather than marketisation and consumerism creating a surplus of choice, which would allow individuals a degree of autonomy, the result is in fact often a scarcity of appropriate resources and essential services, particularly for more vulnerable communities, which means that those most affected by crises such as the Covid-19 pandemic, are the already vulnerable - and their greatest affliction is their lack of choice.

\section{Consumerism hides the reality of how people come into contact with social work}

The third consideration of consumerisation within social work, according to Harris (2014), is the understanding that social work may be less an element of consumer choice than it is a response to stressful conditions, which is evident in the rendering of social work as an essential service in the Covid-19 pandemic. Under the neoliberal assumption of the individual as a rational actor, service users select social work services much as they would products within the market. However, this does not accurately represent the often dire financial, emotional, social and psychological conditions which drive many individuals to seek out, or be referred to, social work services. In turn, the day-to-day complexity of social work intervention and practice is hidden by the neoliberal notion of rational, selfinterested consumer choices (Harris, 2014). These opportunities for choices do not take into account the underlying structural and macro-collective causes that bring individuals into contact with social work (Ornellas \& Engelbrecht, 2020). The reality is that social work intervention is often less of a consumer choice than it is an absolute necessity, involving the interaction of several professions and interactive intervention processes as has become evident in the Covic-19 pandemic. An additional concern here, when considering the impact of both marketisation and consumerisation upon social services, is the prioritisation of the individual, the private sector and the market as holding the answers to social challenges, while there is little understanding of the complexity of social work intervention.

\section{Managerialisation}

The third category of neoliberal influence upon social work is managerialisation which, alongside marketisation and consumerisation, introduces the principles and practices of business into the realm of social work intervention. The assumption underlying the neoliberal concept of managerialism is that organisations, social work services and in fact all operations would be most effective if they functioned by implementing business principles. According to Engelbrecht (2015), this assumption predominantly includes the introduction of managerial norms, a preoccupation with procedures and standards, and the employment of efficiency and cost-effectiveness as the yardsticks by which organisational and social work objectives are identified.

Harris (2014) also argues that managerialism has been adopted within social work as a means of spearheading what he refers to as a permanent revolution in the public sphere, whereby neoliberal ideas are realised through the organisational glue of managerialism. This notion collates with the comment by Clarke (2004: 129) to the effect that "performance is a particular development within this framing of organisational control". Performance indicators are thus developed to measure organisational objectives, establish targets and monitor progress in relation to these identified performance indicators (compare Harris \& Unwin, 2009).

Again, such a simplification of social work does not account for the complexity of the profession's interventions. In addition, the employment of business principles such as cost-effectiveness and standardisation reduces the human element of social work practice to the ticking of boxes and utilisation of statistics (Spolander, 2019). This has often been referred to as the "McDonaldization" (Ritzer, 2011:1) of processes, whereby complex and human-centred processes are broken down into 
repeatable tasks and activities to produce uniform results and outputs. In this way, complex tasks are channelled into clearly labelled boxes that need to be ticked through established procedures, norms and standards. The only concern in such a case is whether social work interventions employed the most efficient use of time, resources and finances, rather than a focus on the holistic, complex and often long-term outcomes of social work practice.

Engelbrecht (2015) points to this escalating emphasis on evidence-based practice as an example of managerialistic influence, whereby only those practices with high quantitative success rates, standardisation potential, and promotional value are regarded as worthy of replication. The impact of this on social work is that for the views and opinions of the profession to be legitimised, there is a need for efficient and quantified knowledge over and above subjectively based human interpretations, which can often be important in the intervention process. Thus, although best practices, in the sense of celebrating and unpacking successful organisational innovations within the social work field, can hold some benefits, the focus on a managerial approach is often one that places efficiency over and above social effectiveness. Of additional concern is that such standardisation of best practices is often implemented with insufficient consideration of context, indigenous knowledge and needs as well as of long-term impact. For example, the long-term socioeconomic impact of emergency measures during the Covid-19 pandemic, such as a temporary fixed increase of welfare grants on households and communities, has yet to be determined beyond the pandemic - and frontline social workers may have to deal with it in a range of social manifestations in future.

Furthermore, in his exposition of social work management versus general business-orientated management principles, which are proposed in a neoliberal discourse, Engelbrecht (2015: 315) offers an exposition of the contrast between social work interventions and management, as opposed to managerialisation, encouraged in a neoliberal environment. This is outlined in Figure 2.

\section{FIGURE 2}

\section{DIFFERENCES BETWEEN SOCIAL WORK MANAGEMENT AND NEOLIBERAL MANAGEMENT (ADAPTED FROM ENGELBRECHT, 2015)}

\begin{tabular}{|l|l|l|}
\hline CHARACTERISTIC & SOCIAL WORK MANAGEMENT & NEOLIBERAL MANAGEMENT \\
\hline Values & Social justice, equality & Self-interest, growth through competition \\
\hline Targets & $\begin{array}{l}\text { Vulnerable individuals, families, groups, communities } \\
\text { and grassroots movements }\end{array}$ & Consumers \\
\hline Accountability & Multiple & Usually single \\
\hline Primary Beneficiaries & Citizens, clients, service users, emerging organisations & Owners, shareholders \\
\hline Primary Funding Sources & Government, donations & Fees, charges \\
\hline Products & Social welfare services & Commercial products and services \\
\hline Legal Considerations & Citizens' rights, government's statutory requirements & Consumers' rights, purchasing power \\
\hline Strategies & Enhancing independence & Creating dependence \\
\hline Ultimate Goal & $\begin{array}{l}\text { Enhancement of people's wellbeing, social } \\
\text { development }\end{array}$ & Maximum profit \\
\hline
\end{tabular}

As demonstrated in Figure 2, neoliberal approaches of self-interest, consumerism, individualism, commercialisation, dependence and profit generation are the antithesis of the social work values of justice, equality, collectivism, citizens' rights, empowerment, development and its services to vulnerable groups. Such a shift in management practices in social work, through the introduction of neoliberal managerialisation can thus hold profound contradictions for the very value base of the

Social Work/Maatskaplike Werk 2020:56(3) 
profession. Harris (2014) offers a complementary summary of three significant areas of managerialism's impact on social work:

- Commodification involves identifying discrete problem categories and a menu of service options in order to quantify and cost service outputs. This often reduces social work to a series of once-off transactions, depriving it of meaningful working relationships with and commitments to service users;

- Reducing funding to produce efficiency gains exerts downward pressure on costs by imitating the pressure towards falling profits in capitalist markets;

- Exerting greater control over professional space, for example through the use of "dashboards" as a means of heightening surveillance of the work of individual social workers and groups of social workers.

In addition, Sewpaul and Hölscher (2004) and Ornellas and Engelbrecht (2020) observed the following as consequences of a managerial approach towards social work:

- Tunnel vision: an emphasis by managers on phenomena that are quantified in the performance management system at the expense of unquantified aspects of performance; and

- Gaming: the minimising by managers of the apparent scope for performance improvement to avoid increased expectations and higher targets in the future.

Of importance for social work practices is the development of a critical awareness of the use of neoliberal discourse and narrative to construct (or rather cloak) the meaning under the guise of what can appear to be more human-orientated concepts. For example, managerialisation is often introduced under the banner of accountability, transparency, fiscal austerity and public legitimacy (Clarke, 2004; Engelbrecht, 2015; Spolander, 2019), all of which can be considered to be reasonable and necessary considerations - specifically in times of a pandemic. However, a notion of managerialisation which holds as its key objective the cutting of costs regardless of social justice or human impact does not align with the core values of the profession and has drastic consequences for the socioeconomic wellbeing and resilience of communities. Cutting costs, a focus on cost efficiency and the prioritisation of economic considerations over human life have left communities and individuals extremely vulnerable to crises such as Covid-19. In this regard, Sewpaul and Hölscher (2004: vii) warn of the profession falling "prey to the 'realism of neoliberalism'... [which] demands a technical, managerial and apolitical approach to re-addressing poverty". Hence, one of the biggest threats to the social work profession, in contrast with the profession's values and academic inclination (compare the global definition of social work, IFSW 2014) in times of the Covid-19 pandemic, could be that social worker-service user relationships, as part of governments' responses to the pandemic, may be potentially reduced to simplistic social work commodifications and resultant once-off transactions. The use of social workers merely to distribute food relief to service users during the times of the pandemic may serve as an example and mirrors the discussion below on the deprofessionalisation of the social work profession.

\section{Deprofessionalisation}

The fourth category of the neoliberal impact on social work is deprofessionalisation. As implied by Ornellas and Engelbrecht (2020), this impact is largely a culmination of marketisation, consumerisation and managerialisation, resulting in a reduced level of professional discretion and autonomy. With the neoliberal promotion of the private sector and its business principles, the task of social work is increasingly being given over to less qualified workers, such as care and social auxiliary workers or entirely alternative professions (Engelbrecht, 2015). While these practitioners are valuable as complementary and supporting agents in social service delivery, they may be viewed as more costeffective replacements of social work professionals, rather than merely additional professional support, since their employment costs are usually lower than those of graduates of the social work profession. 
This, in addition to the commodification of the social work profession (as illustrated above) serves to significantly undermine the value of the social work profession as a scientific and academic discipline (IFSW, 2014). Engelbrecht (2015) also points to the employment of non-social workers to manage and supervise professional social workers, with little knowledge of social work theories and practices. Nonsocial work managers would often enforce business-like principles and expectations with very little understanding of social work intervention processes. As argued by Engelbrecht (2015), this is a direct result of neoliberal managerialisation and marketisation, rather than of incompetence or a scarcity of senior and competent social workers. In the wake of the Covid-19 pandemic (and beyond), quantifiable statistics on specific social interventions are of utmost importance for political spin, and social work may be a handy profession to be utilised for these purposes by anybody with political ambitions.

The result, as shown by the above exposition, is a deskilling of the social work profession and an undermining of scientific complexity and of scholarly decision making by social workers. The professional role of social work is thus being largely contested, as its claims to be a specialist body of academic knowledge have been eroded in the past (Ornellas \& Engelbrecht, 2020). Moreover, the independent functioning of social work practitioners, without being controlled by politically inspired managers, government ideologies and donors, may be questioned in future, beyond the Covid-19 pandemic. The impact of marketisation, consumerisation and managerialisation, which has reduced social work to the ticking of boxes and cost-effective standardisation of interventions, further undermines the autonomy and discretion of social work professionals in their day-to-day practice; and as the complexity of social work intervention is reduced to measurable statistics, the idea that this profession can be replaced with lesser or alternatively qualified individuals (regarded as being more cost-effective) becomes increasingly viable, especially beyond the current pandemic, which will leave the world facing an economic crisis unprecedented since the Depression. Ultimately, marketisation, consumerisation, managerialisation and specifically deprofessionalisation diminish the social worker's professional identity. Harlow, Berg, Barry and Chandler (2012), who observed this progressive tendency nearly a decade ago, viewed this shift as a blurring of professional boundaries, under the guise of streamlining service provision and encouraging a more flexible workforce. The contradiction of this, however, is the recognition of social work as an essential service in the midst of the Covid-19 pandemic (News 24, 2020), but within the parameters of a neoliberal reform that has as its main aim to reset and to reinstall the economy beyond the pandemic.

\section{CONCLUDING REMARKS}

The identity, values and practice of the social work profession are facing severe challenges as a result of neoliberal reform. These challenges are not abstract or isolated, or reducible to merely academic analysis, but are affecting the day-to-day practice of the frontline social worker, and they were experienced before the Covid-19 pandemic and will continue beyond the pandemic. Neoliberal marketisation is resulting in an escalating outsourcing of social work services and the state distancing itself from its responsibility to deliver welfare and offer economic and structural support to NGO groups that are required to fill this vacuum. The social worker-service user relationship is becoming one of contractor and consumer, blaming individuals and communities for the challenges they are facing under a structurally defective system. The consumerisation of social work promotes individual and individualistic interventions over and above addressing macro and structural needs through a collective approach.

The managerialisation of social work has reduced social work intervention to the ticking of boxes and the evaluation of the cost-effectiveness and efficiency of activities performed, rather than assessing the human impact. With the standardisation of social work activities under the guise of evidence-based work and best practice, social work is deskilled, devalued and deprofessionalised. The profession has throughout history been influenced by political and economic priorities. Understanding this, social workers should become keenly aware of global realities and forces (compare Jones \& Truell, 2012). The impact of neoliberalism on the social work profession could be absolute and hidden, if it is not Social Work/Maatskaplike Werk 2020:56(3) 
monitored more closely, especially during the Covid-19 pandemic and beyond, where the focus of governments will be to normalise societies again.

Therefore, it is imperative to note that a critical analysis of the neoliberal impact on social work (as in this article) should not be seen as undermining or critiquing the essential and valuable work that the social work profession continues to do globally from one day to the next - the valuable role which has been made even more apparent during this pandemic time. Rather, the contention is that the very crux of this critique re-emphasises the intrinsic value of social work and the potential of a redistributive and truly remarkable profession that should not be undermined or swayed by political ideologies and economic forces that do not serve in a humane way the communities that social work professes to protect. It is only through an honest account of past and present contradictions, discourses and underlying meanings that an authentic interpretation of present-day endeavours, and an impactful mapping of future undertakings, can be achieved.

It is essential that the social work profession should be aware of often hidden neoliberal impacts so that it can stand its ground in an increasingly volatile neoliberal world. In the wake of the Covid-19 crisis and beyond, the devastating impacts of an individualised, cost-effective and business-driven social work profession are impossible to ignore. As professionals, social workers need to critically reflect on how they may be, unknowingly, promoting a neoliberal discourse and economy-centric values, and recognise the direct contradictions these hold for the mandate of the social work profession.

\section{REFERENCES}

BUCHBINDER, E., EISIKOVITIS, Z. \& KARNIELI-MILLER, O. 2004. Social workers' perceptions of the balance between the psychological and the social. Social Service Review, 78(4):531-552.

BUTCHER, T. 1995. Delivering welfare: The governance of the social services in the 1990s. Buckingham: Open University Press.

CLARKE, J. 2004. Dissolving the public realm? The logics and limits of neo-liberalism. Journal of Social Policy, 33(1):27-48.

DEPARTMENT OF SOCIAL DEVELOPMENT (DSD). 2016. Comprehensive report on the review of the white paper for social welfare, 1997. [Online] Available: https://www.gov.za/sites/default/files/gcis_document/201610/comprehensive-report-white-paper.pdf

[Accessed: 20 March 2020].

ENGELBRECHT, L.K. 2015. Revisiting the esoteric question: Can non-social workers manage and supervise social workers? Social Work/Maatskaplike Werk, 51(3): 311-331.

FERGUSON, I., LAVALETTE, M. \& WHITMORE, E. 2005. Globalisation, global justice and social work. London: Routledge.

FINE, B. \& LEOPOLD, E. 1993. The world of consumption. London: Routledge.

FLYNN, N. 2007. Public sector management (5th ed). London: Sage.

FROGGETT, L. 2002. Love, hate and welfare. Psychosocial approaches to policy and practice. Bristol: Policy Press.

GRAY, M. 1998. Welfare policy for reconstruction and development in South Africa. International Journal of Social Work, 41(1):23-37.

HARLOW, E., BERG, E., BARRY, J. \& CHANDLER, J 2012. Neoliberalism, managerialism and the reconfiguring of social work in Sweden and the United Kingdom. Organisation, 20 (4): 534-50.

HARRIS, J. 2003. The social work business. New York: Routledge.

HARRIS, J. 2014. (Against) neoliberal social work. Critical and Radical Social Work, 2(1):7-22. 
HARRIS, J. \& UNWIN, P. 2009. Performance management in modernised social work. In: HARRIS, J. \& WHITE, V. (eds). Modernising social work: Critical considerations. Bristol: Policy Press.

HARVEY, D. 2005. A brief history of neoliberalism. Oxford: Oxford University Press.

HARVEY, D. 2007. Neoliberalism as creative destruction. The Annals of the American Academy of Political Science, 610(1):21-44.

HARVEY, D. 2014. Seventeen contradictions and the end of capitalism. London: Profile Books.

HAY, C. 2002. Globalization as a problem of political analysis: Restoring agents to a process without a subject and politics to a logic of economic compulsion. Cambridge Review of International Affairs, 15(3):379-392.

HOWE, D. 1996. Surface and depth in social-work practice. In: PARTON, N. (ed). Social theory, social change and social work. London: Routledge.

IFE, J. 2000. Localized needs and a globalized economy: Bridging the gap with social work practice. Canadian Social Work, Special Issue: Social Work and Globalization, 2(1):50-64.

INTERNATIONAL FEDERATION OF SOCIAL WORKERS (IFSW). 2014. Global definition of social work [Online] Available: https://www.ifsw.org/what-is-social-work/global-definition-of-socialwork/_[Accessed: 20 March 2020].

INTERNATIONAL LABOUR ORGANIZATION (ILO). 2020. The impact of COVID-19 on inequalities in the world of work. [Online] Available: International Labour Organization. 2020. The impact of COVID-19 on inequalities in the world of work.https://www.ilo.org/global/about-theilo/multimedia/video/institutional-videos/WCMS_740289/lang--en/index.htm [Accessed: 14 April 2020].

INTERNATIONAL MONETARY FUND (IMF). 2020. The Great Lockdown: Worst economic downturn since the great depression. [Online] Available: https://blogs.imf.org/2020/04/14/the-greatlockdown-worst-economic-downturn-since-the-great-depression/ [Accessed: 14 April 2020].

JONES, C. 2001. Voices from the frontline: State social workers and new labour. The British Journal of Social Work, 31(4):547-562.

JONES D, N. \& TRUELL, R. 2012. The global agenda for social work and social development: A place to link together and be effective in a globalized world. International Social Work, 55(4):454472.

LYMBERY, M. 2001. Social work at the crossroads. British Journal of Social Work, 31:369-384.

MARTIN LUTHER KING JR. 1963. I have a Dream. Address at march on Washington for jobs and freedom. August 28. Washington, D.C.

MCDONALD, C. 2006. Challenging social work: The institutional context of practice. Basingstoke: Palgrave Macmillan.

MIDGLEY, J. 1997. Social welfare in global context. Thousand Oaks: Sage.

NEEDHAM, C. 2006. Customer care and the public service ethos. Public Administration, 84(4):845860.

News 24, 2020. These are the permissions and restrictions for Level 4 lockdown, [Online] Available: https://www.news24.com/SouthAfrica/News/see-these-are-the-permissions-and-restrictionsfor-level-4-lockdown-20200425 [Accessed: 25 April 2020].

ORNELLAS, A., ENGELBRECHT, L.K., MARTÍNEZ-ROMÁN, M. A., TORTOSA-MARTÍNEZ, J., CASANOVA, J. L., \& DAS DORES GUERREIRO, M. 2017. Neoliberalism and austerity in Spain,

Social Work/Maatskaplike Werk 2020:56(3) 
Portugal and South Africa: The revolution of older persons. Journal of Gerontological Social Work, 60 (6-7): 535-552.

ORNELLAS, A., SPOLANDER, G. \& ENGELBRECHT, L.K. 2018. The global social work definition: Ontology, implications and challenges. Journal of Social Work, 18(2): 222-240.

ORNELLAS, A., SPOLANDER, G., ENGELBRECHT, L.K., SICORA, A., PERVOVA, I., MARTÍNEZ-ROMÁN, M., LAW, A.K., SHAJAHAN, PK., DAS DORES GUERREIRO, M., CASANOVA, J.L., GARCIA, M.L.T, ACAR, H., MARTIN, L., \& STRYDOM, M. 2019. Mapping social work across 10 countries: Structure, intervention, identity and challenges. International Social Work, 62(4): 1183-1197.

ORNELLAS, A. \& ENGELBRECHT, L.K. 2020. Neoliberal impact on social work in South African non-governmental organisations. Southern African Journal for Social Work and Social Development, 32(1): 1-21.

ORNELLAS, A., ENGELBRECHT, LK. \& STRYDOM, M. 2020. South Africa's social policy dynamics, developments and well-being: Between developmentalism and the open-market. In: PERVOVA, L. (ed). Neoliberalism, social policy and welfare in developing countries (Russia, India and South Africa). Newcastle upon Tyne, UK: Cambridge Scholars Publishing.

PIERSON, C. 1991. Socialism after communism: The new market socialism. Canada: Pennsylvania State University Press.

RITZER, G. 2011. The McDonaldization of society 6. London: Sage Publications.

SEWPAUL, V. 2013. Neoliberalism and social work in South Africa. Critical and Radical Social Work, 1(1):15-30.

SEWPAUL, V. \& HÖLSCHER, D. 2004. Social work in times of neoliberalism: A postmodern discourse. Pretoria: Van Schaik Publishers.

SMITH, L. 2014. Historiography of South African social work: Challenging dominant discourses. Social Work/Maatskaplike Werk, 50(3):305-331.

SPOLANDER, G., ENGELbRECHT, L. K., MARTIN, L., STRYDOM, M., PERVOVA, I., MARJANEN, P., TANI, P., SICORA, A. \& ADAIKALAM, F. 2014. The implications of neoliberalism for social work: Reflections from six country international research collaboration. International Social Work, 57(4):300-311.

SPOLANDER, G., ENGELBRECHT, L.K. \& PULLEN-SANSFAÇON, A. 2016. Social work and macro-economic neoliberalism: Beyond the social justice rhetoric. European Journal of Social Work, 19(5): 634-649.

SPOLANDER, G. 2019. The impact of neoliberalism on management and supervision In: ENGELBRECHT, L.K. (ed). Management and supervision of social workers: Issues and challenges within a social development paradigm. (2nd ed). Andover: Cengage Learning EMEA Limited.

STANIFORTH B., FOUCHÉ C. \& O’BRIEN M. 2011. Still doing what we do: Defining social work in the 21st century. Journal of Social Work, 11(2):191-208.

WORLD HEALTH ORGANIZATION (WHO). 2020. Coronavirus disease (COVID-19) pandemic. [Online] Available: https://www.who.int/emergencies/diseases/novel-coronavirus-2019 [Accessed: 1 May 2020]. 